Canadian Journal of Family and Youth, 7(1), 2015, pp 115-148

ISSN 1718-9748 ( ) University of Alberta

http://ejournals.library.ualberta.ca/index/php/cjfy

\title{
Is There Racial Discrimination in Police Stop-and-Searches of Black Youth? A Toronto Case Study
}

\author{
Meng, Y., Giwa, S. \& Anucha, U.
}

\begin{abstract}
Our study investigated racial profiling of Black youth in Toronto and linked this racial profiling to urban disadvantage theory, which highlights neighbourhood-level processes. Our findings provide empirical evidence suggesting that because of racial profiling, Black youth are subject to disproportionately more stops for gun-, traffic-, drug-, and suspicious activity-related reasons. Moreover, they show that drug-related stop-and-searches of Black youth occur most excessively in neighbourhoods where more White people reside and are less disadvantaged, demonstrating that race-and-place profiling of Black youth exists in police stop-and-search practices. This study shows that the theoretical literature in sociology on neighbourhood characteristics can contribute to an understanding of the relationship between race and police stops in the context of neighbourhood. It also discusses the negative impact of racial profiling on Black youth.
\end{abstract}

Yunliang Meng is an Assistant Professor in the Department of Geography at Central Connecticut State University. From 2010 to 2013, he worked as a postdoctoral fellow at the School of Social Work, York University. Dr. Meng's research interests include geographic information systems (GIS), public participatory planning, and quantitative analysis. His research in these areas has been published in a variety of urban and GIS journals. In addition, he has a longstanding research interest in the issue of discrimination and racial profiling in the City of Toronto. Sulaimon Giwa is a doctoral candidate at the School of Social Work, York University. He is also the Community Parole Officer responsible for Aboriginal and non-Aboriginal men serving federal and provincial sentences at Waseskun Healing Center, Saint-Alphonse-Rodriguez, Québec. His applied research program and professional activities centralize critical race transformative pedagogies and theories as frameworks and analytic tools for social justice and equity. Scholarly work in these areas has appeared in learned journals. For two years, he coordinated a first-of-its kind, federally funded, community-based participatory project addressing racism and racial profiling in policing in Ottawa, Ontario. As well, he completed internship and professional trainings with the Ottawa Police Service Diversity and Race Relations Section, the Peterborough Lakefield Community Police, and the Toronto Police Service. Uzo Anucha is Associate Professor and Graduate Program Director at the School of Social Work, York University. In all her professional activities, Dr. Anucha seeks to bridge the gap between knowledge production and knowledge use. She is principal investigator of Assets Coming Together for Youth, a community-university research partnership focused on developing a comprehensive youth strategy for the Jane-Finch community in Toronto. Dr. Anucha has served on a variety of community-based boards and is currently on the board of the Central Local Health Integration Network. 
Meng, Giwa, and Anucha

\section{Background}

Similar to Harris's (1997) findings in the United States, Black people in Toronto have long complained that they are frequently stopped, questioned, and searched by the police for DWBBs_- "Driving While Being Black Violations" (Foster, 1996; Wortley \& Tanner, 2004). The Toronto Star (hereafter referred to as the Star) investigated these complaints for over two years, analyzing race and crime statistics gathered from a Toronto Police Service (TPS) database that documented arrests made and charges laid. The results, published in 2002, revealed that Black people in Toronto were highly overrepresented in charges stemming from drug possession and “out-of-sight” traffic violations (e.g., driving without a licence or insurance). Based on these findings, the Star concluded that Toronto police "stop people for little reason other than their skin colour" (Rankin, Quinn, Shephard, Simmie \& Duncanson, 2002a, p. A1). In other words, they engaged in racial profiling.

In response, the TPS retained Gold and Harvey (2003) to conduct a review of the Star's findings; they concluded that the Star's research was "junk science” (Toronto Police Service, 2003, p. 1). In a further move to discredit the Star, the Toronto Police Services Board denied all allegations of racial bias, a position bolstered by the then Chief of Police, Julian Fantino, who declared that "we do not do racial profiling.... There is no racism" (Rankin, Quinn, Shephard, Simmie, \& Duncanson, 2002b, p. A1). He gave no concrete empirical evidence to support his argument. Although some researchers (Gold \& Harvey, 2003; Harvey \& Liu, 2003; Melchers, 2003; Wortley \& Tanner, 2004) pointed out the data bias, benchmark weaknesses, and inference errors associated with the analysis done by the Star, they could not provide concrete evidence to support the "we do not do racial profiling" argument.

Given the undisputed tensions between police and the Black community, the first objective of our study was to provide more empirical evidence and in-depth discussion on 
Discrimination in Police Stop-and-Searches

whether racial profiling of Black youth exists in stop-and-searches conducted by Toronto police. Notwithstanding the number of studies done by scholars, media, and police of racial profiling in general, little research has focused on the issue of racial profiling of Black youth in Toronto. Although racial profiling affects Black people of every age, Black youth are very likely to be targeted: they are major users of public spaces, and race-based stereotypes attribute a greater propensity for antisocial behaviour to them (Eid, Magloire, \& Turenne, 2011). Research has found that police negatively associate minority race and criminality, which in turn generates distrust of the police among Black youth, contributing to the deterioration in their relationship (Giwa, James, Anucha, \& Schwartz, 2014; Lurigio, Greenleaf, \& Flexon, 2009). Indeed, Black youths' perception of racial bias in police stops and searches is particularly widespread in Toronto (Neugebauer, 2000).

The Star's latest analysis (Winsa \& Rankin, 2012) showed that Black youth are more likely than White youth to be stopped and documented in each of the city's 73 police patrol zones. Toronto police have defended this practice as good police work in high crime areas (Winsa \& Rankin, 2012). In the past, they have also emphasized that Black youth are more likely to be involved in homicides and in crimes involving drugs and firearms (Toronto Police Accountability Coalition, 2010). To solidify their view on crime involvement among Black youth, the police initiated what legal scholar David Tanovich has called "a no-walk list" (Tanovich, 2007, p. 1) — as pedestrians, Black youth in Toronto are required not only to carry identification but to consent to questioning and searches.

Police officers often develop and use area knowledge (Bittner, 1970), territorial knowledge (Brown, 1981), and knowledge of crime hot spots (Sherman, Gartin, \& Buerger, 1989) when they work in the field. Police assessment of perceived risk is linked to their concept 
Meng, Giwa, and Anucha

of public place, which influences their response and actions (Meehan \& Ponder, 2002). Police actions such as racial profiling are therefore "inextricably tied not only to race, but to officers' conceptions of place, of what should typically occur in an area and who belongs, as well as where they belong" (Meehan \& Ponder, 2002, p. 402). Some policing studies suggest that minorities are more likely to be stopped in areas where they look "out-of-place" (Meehan \& Ponder, 2002; Stults, Parker, \& Lane, 2010). In Toronto, this point of view is partly supported by the Star's findings that differences between Black and White stop rates are highest in the more affluent, mostly White areas of the city (Rankin, 2010).

Others suggest that disproportionate stops of racial minorities tend to occur in disadvantaged minority neighbourhoods (Roh \& Robinson, 2009; Stults et al., 2010; Tanovich, 2002). In Toronto, this point of view is partly supported by Tanovich, who argued that racial profiling has criminalized many predominantly Black neighbourhoods in Toronto commonly referred to by the police as high crime areas (and see section 2.3 below for a further discussion of this topic).

No matter what point of view researchers hold, neighbourhood characteristics (e.g., racial and socioeconomic characteristics) are important in differentiating police stops for minorities spatially. However, much of the research on racial profiling in Toronto has tended to ignore the neighbourhood context. To allow us to fully understand racial profiling of Black youth in the context of place, the second objective of our study was to examine whether disproportionate stops of Black youth tended to occur in areas where certain neighbourhood characteristics were also present. We investigated these two research objectives by analyzing police stops in terms of their drug-, traffic-, suspicious activity-, and gun-related grounds. Our approach differed from the Star analysis, which did not differentiate stoppage reasons (Winsa \& Rankin, 2012); we 
selected these police practices because they offered the more commonly suspected, if not necessarily the most likely, window through which to observe racial bias in policing.

Our paper is organized as follows: Section 2 provides a working definition of racial profiling, a discussion of the Star's analysis and a brief review of the connection between urban disadvantage and social disorganization theories on the study of racial profiling within a neighbourhood context. Section 3 outlines our research methods, along with a description of the study area, data procedures, and analytic approach. Section 4 presents our main findings, and in Sections 5 and 6, respectively, we discuss our findings and conclusions.

\section{Literature Review}

\subsection{Defining Racial Profiling}

The Ontario Human Rights Commission (2003) defines racial profiling as

....any action undertaken for reasons of safety, security, or public protection that relies on stereotypes about race, colour, ethnicity, ancestry, religion, or place of origin, or a combination of these, rather than on a reasonable suspicion, to single out an individual for greater scrutiny or different treatment. (p. 6)

Racial profiling by police is said to occur in situations where race stands in as a proxy for risk in the policing of criminality (Giwa et al., 2014; Harris, 2003). This is the case, for example, when racial disparities are found in police stop-and-search practices in which racial minorities are more likely than their White counterparts to be stopped for traffic-, drug-, and gun-related reasons (Bostaph, 2007; Harris, 1999; Wortley \& Tanner, 2004). In the criminological literature, other forms of racial profiling are also said to exist where racial disparities are found in Customs searches at airports and border crossings, increased police patrols in minority neighbourhoods and undercover activities, and sting operations that target particular ethnic groups (Wortley \& Tanner, 2004). In situations of police stops, moreover, studies show that the police treat racial minorities more harshly than Whites (e.g., Engel \& Calnon, 2004; Roh \& Robinson, 2009). 
Meng, Giwa, and Anucha

Empirical evidence of racial disparities in police stop-and-search actions is clear, bolstering claims of racial profiling; however, American studies have often reported mixed conclusions based on similar empirical findings. In the earliest round of racial profiling enquiries, reputable New Jersey and Maryland studies indicated that racial minorities were stopped disproportionately more than their representation in population statistics (Engel, Calnon, \& Bernard, 2002). The results of later studies also documented stoppage disparities, but generally were less inclined to conclude that discrimination drove them (Buerger, 2009). Importantly, the later studies occurred in a climate where police and civic officials were well aware of the racial profiling debate, so that police agencies may have been more likely to take steps to minimize racial disparity, and were likely more politically astute in their interpretation of findings (Buerger, 2009).

\subsection{The Star's Analysis}

The Star's research team, led by Dr. Michael Friendly, worked with 4,696 out-of-sight offences reported between 1996 and 2002 for which skin colour was recorded for purposes of identification. Of these, 33.6 percent out-of-sight offence drivers were "Black." Based on the assumption that "random checks would generate a pattern of charges that mimics the racial distribution of drivers in society as a whole" (Rankin et al., 2002a, p. A1), the Star used the proportion of the Toronto's residential population who reported themselves as Black on the 1996 Census forms (8.1 percent) as the risk set or benchmark against which to compare the racial distribution of stopped drivers. Two major problems are associated with using the residential population as the benchmark. First, the residential population is an appropriate base or denominator for statistics that measure prevalence. However, counts of police stops, arrests, or crimes measure the number of incidents. Using counts of police stops divided by population numbers from census creates base error. The second problem lies in the unrealistic assumption of 
Discrimination in Police Stop-and-Searches

randomness in police vehicle stops, since police patrols and stops are most effectively deployed when they focus on when and where problems are most expected (Melchers, 2003). In addition, of the 7,511 out-of-sight offences reported over a five-year period, 4,696 (63 percent) contained complete information. For the other 2,815 offences, the drivers' skin colour was not recorded. Missing such a large number of skin colour data creates an issue of sample bias. Despite the data bias and benchmark weaknesses, the Star's research team still made strong — although controversial and maybe faulty — racial profiling inferences that later received supporting or refuting statements from judges, attorneys, crown prosecutors, and police officials throughout Ontario’s criminal justice system (Melchers, 2003).

\subsection{Connecting Urban Disadvantage and Social Disorganization Theories to the Study of Racial Profiling}

Research on police behaviour has long noticed that police use of discretion varies according to neighbourhood characteristics in addition to individual-level factors (e.g., Bass, 2001; Herbert, 1997; Milovanovic \& Russell, 2001; Smith, 1986). Racial profiling thus clearly

seems to be a behaviour influenced by the context of the neighbourhood. Many case studies have focused on the existence of racial profiling in police stop-and-search practices in Toronto, but few include consideration of the spatial elements of police stops. It is very challenging to establish the social mechanisms that link racial profiling behaviour at the individual level to a larger ecological context (Parker, MacDonald, Alpert, Smith, \& Piquero, 2004; Sampson, 2000; Short, 1998). However, the urban disadvantage and social disorganization literature (Bursik, 1988; Shaw \& McKay, 1942; Wilson, 1987, 1996) offers opportunities to link the two components.

Social disorganization theory is a cornerstone in the study of crime. Structural conditions such as low socioeconomic status, racial heterogeneity, residential instability, and family 
Meng, Giwa, and Anucha

disruption are key to this perspective, as they lead to the breakdown in social control, resulting in crimes (Parker et al., 2004). Central to the theory is the idea that structural barriers hinder development of formal and informal ties that promote the community's ability to solve common problems (Parker et al., 2004). Bursik (1988) defined social disorganization as a community structure that fails to maintain effective social control. Shaw and McKay (1942) argued that deteriorating structural conditions lead to social disorganization in urban neighbourhoods, which in turn explains the spatial variations in crime rates.

The urban disadvantage perspective finds its origins in the social disorganization tradition; the two are highly interrelated. Wilson (1987) argued that since the 1970s, the shift from manufacturing to service and retail jobs in many urban areas in North America eliminated many job opportunities in urban neighbourhoods, thereby increasing poverty, unemployment, and isolation in areas usually dominated by minorities, since different races tend to cluster in different areas of a large metropolitan city (e.g., Fong, 1996; Harney, 1985; Hou \& Picot, 2004). Urban disadvantage, a consequence of this urban transformation (Ricketts \& Sawhill, 1988; Wilson, 1996), has been linked to an increase in urban crime rates (Krivo \& Peterson, 1996; Land, McCall, \& Cohen, 1990; Parker \& McCall, 1999). Given that urban disadvantage and social disorganization theories have the same origin, and that the socioeconomic indicators advanced in both theories are highly correlated, we felt confident in focusing on using urban disadvantage theory to link racial profiling to the ecological context of neighbourhoods in Toronto.

Police usually respond to the crime rates in various neighbourhoods by applying different crime-control strategies, and problem-oriented policing strategies are considered appropriate methods to allocate limited police resources (Paulsen \& Robinson, 2004). More police stops are 
Discrimination in Police Stop-and-Searches

likely to be practised in neighbourhoods that have more reported crimes (Doerner, 1997; Roh \& Robinson, 2009). Consequently, disproportionately more police stops practised in crime "hot spots" can be perceived as police efforts to battle crimes, and police stops and crimes are likely to be correlated. In a highly ethnically diverse city such as Toronto, crime hot spots often intersect with disadvantaged neighbourhoods that may have a high proportion of racial minorities. As Roh and Robinson (2009) argued, a disproportionately higher police presence along with vigorous law enforcement is a common practice in disadvantaged and racialized neighbourhoods (see also Giwa et al., 2014). This difference in patrol intensity could account for some of the disproportionality in Black stop-and-arrest rates (Blumstein, 1982). Therefore, some researchers have proposed, the likelihood of racial minorities being stopped by police is higher in disadvantaged, racialized, and more crime-prone neighbourhoods, due to the overrepresentation of these groups in these areas (Roh \& Robinson, 2009; Stults et al., 2010).

Some researchers have suggested that the likelihood of racial minorities being stopped is greater in areas where the racial minorities look "out of place" than in areas where their skin colour is prominent (Meehan \& Ponder, 2002; Stults et al., 2010). The relationship between place-based disadvantage and crime is very pronounced in many racial minority neighbourhoods, so police officers tend to suspect that racial minorities might be engaged in criminal activities when they appear in White and wealthy neighbourhoods. As a result, disproportionately more stops of racial minorities are likely to happen in areas that are less racialized and disadvantaged. This situation is exacerbated by a recent trend in which more and more minority people are moving into residential areas that were once predominantly White neighbourhoods, a development that could lead to conflicts between racial groups and cause the use of formal social control sanctions against minority groups (Brown \& Warner, 1992; Myers, 1990). 
Meng, Giwa, and Anucha

Given the possibility of racial profiling, and the relationship between neighbourhood characteristics and the level of police stops of racial minorities, our study poses the following questions:

$\mathrm{H}_{1}$ : $\quad$ Are Black youth subject to disproportionately more drug-, traffic-, suspicious activity-, and gun-related police stops than White youth?

$\mathrm{H}_{2 \mathrm{a}}$ : Does the rate of police stops involving Black youth increase as a more concentrated level of urban disadvantage and racialization increases?

$\mathrm{H}_{2 \mathrm{~b}}$ : Does the rate of police stops involving Black youth increase as a more concentrated level of urban disadvantage and racialization decreases?

\section{Methodology}

\subsection{Study Area}

The City of Toronto is located in southern Ontario on the northwestern shore of Lake Ontario (see Figure 1). It is home to more than 2.7 million people (City of Toronto, 2013) and is the centre of one of North America's most dynamic regions - the Greater Toronto Area (GTA). The capital of the province of Ontario, Toronto is arguably the cultural, entertainment, and financial centre of Canada. Demographically speaking, it is one of the world's most diverse cities in terms of percentages of non-native-born and visible-minority residents. Half of Torontonians were born outside Canada; 47 percent identify as members of ethnoracial minorities (City of Toronto, 2013). Given this demographic makeup, Toronto is a particularly important geographic location in which to conduct a case study of racial profiling. 


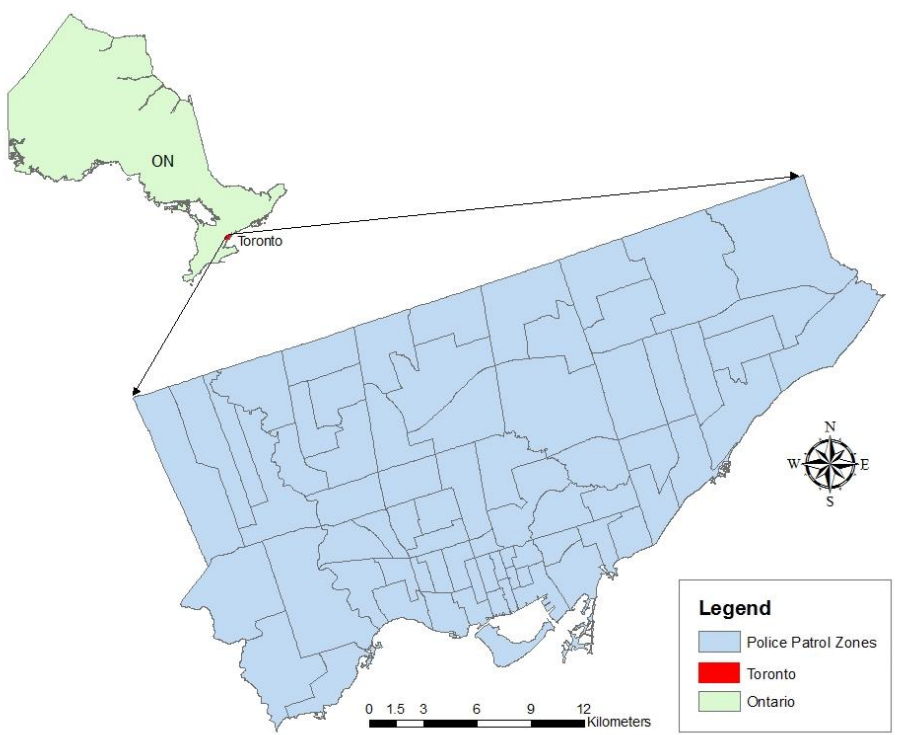

Figure 1. Study area.

\subsection{Data Procedures and Analytic Approach}

Police stop data used in this study were generated from police-initiated stops including in-vehicle and pedestrian stops and searches, recorded on the field information reports (known as 208 cards) that Toronto police use daily to record information about individuals they stop and question on the street, in mostly noncriminal encounters. Included on the 208 cards are details on the person's name, address, age, gender, contact location (or police patrol zone), contact time, birthplace, skin colour (e.g., Black, White) as reported by the police officer, and stop reason (e.g., general investigation, loitering, drug, or traffic stop). These personal details were deleted before we were allowed access to the data.

Our study included only youth between the ages of 15 and 29 (the Commonwealth definition of youth). The dataset captured details from 162,377 contact cards filled out by Toronto police officers regarding 116,374 youths stopped in 2008. If a single youth was stopped a number of times during a specific period that was recorded on multiple 208 cards. Racial 
Meng, Giwa, and Anucha

composition data from the 2006 population census (Statistics Canada, 2006a) were used as a benchmark against which to compare the racial distribution of people stopped. We gathered neighbourhood characteristic data from the 2006 census data as well.

Racial groups considered in this study were Black and White. The level of racialization in a neighbourhood was represented by the percentage of Whites in the residential population (see Table 1). The indices used to measure the level of disadvantage in a neighbourhood included the percentage of single-parent families, unemployment rate, and government transfer payments as a percentage of total income (see Table 1). Government transfer payments were all cash benefits received from federal, provincial, territorial, or municipal governments during 2005. This variable was derived by summing the amounts calculated by Statistics Canada, as reported in the Old Age Security Pension and Guaranteed Income Supplement, Allowance and Allowance for the Survivor; benefits from Canada or Québec Pension Plan; benefits from Employment Insurance; and child benefits and other income from government sources.

Racial and socioeconomic data at dissemination area (DA) level were carefully aggregated to the level of police patrol zones for neighbourhood-level analysis using the polygon-in-polygon analysis method, in Hawth's analysis tools designed for ArcGIS 9.3 (Beyer, 2004). At the time of our research, there were 73 police patrol zones in Toronto (see Figure 1). Although these zones were not explicitly considered neighbourhoods, they have been used in extant research as units of analysis that correspond to actual neighbourhoods (e.g., Gamble et al., 2002; Gudell \& Skogan, 2003; Roh \& Robinson, 2009). 
Discrimination in Police Stop-and-Searches

Table 1

Neighbourhood Racial and Socioeconomic Characteristics

\begin{tabular}{llc}
\hline & Neighbourhood Racial and Socioeconomic Characteristics & Unit \\
\hline Level of Racialization & White population & percent \\
Level of Disadvantage & Single-parent families & percent \\
& Unemployment rate & percent \\
& Government transfer payments & percent \\
\hline
\end{tabular}

To calculate the rates at which Black or White youth were stopped by police for traffic-, drug-, gun-, and suspicious activity-related reasons, we divided the number of stops of Black or White youth attributed to a particular reason by the population of Black or White youth in the city or patrol zone in question, to obtain a stops-per-100 population figure. Many demographic and socioeconomic variables in the census were intercorrelated. Spearman's correlation coefficient $\rho$ (Spearman, 1904) was used to test the correlations among neighbourhood racial and socioeconomic characteristics, since it did not assume normality and was robust to outliers. Principal component analysis (PCA) was then used to tackle the intercorrelation problem and generate a smaller set of uncorrelated factor scores (Hotelling, 1933; Jolliffe, 2002). Finally, score values of selected factors were used as independent variables in a multiple linear regression model (Mardia, Kent, \& Bibby, 1979) for predicting the rates at which Black youth were stopped by police for traffic-, drug-, gun-, and suspicious activity-related reasons.

\section{Results}

\subsection{Descriptive Statistics}

Descriptive statistics regarding population and various stops practised by Toronto police are shown in Figure 2. Although at the city level only 10.4 percent of Toronto's total youth population was Black (Statistics Canada, 2006b), they made up 24.6 percent of young people stopped for drug reasons, 28.6 percent for traffic reasons, 27.3 percent for suspicious activities, 
Meng, Giwa, and Anucha

and 45.6 percent for stops relating to gun possession. Meanwhile, White youth, who made up more than 46.7 percent of Toronto's youth population (Statistics Canada, 2006b), accounted for 46.8 percent of those stopped in drug cases, 34.2 percent for traffic reasons, 39.8 percent in the suspicious activity category, and 25.3 percent for gun-related stops. In relating Black and White youth percentages of the population to stops caused by various reasons, it is clear that Black youth, more than White youth, were overrepresented in stops conducted by Toronto police.

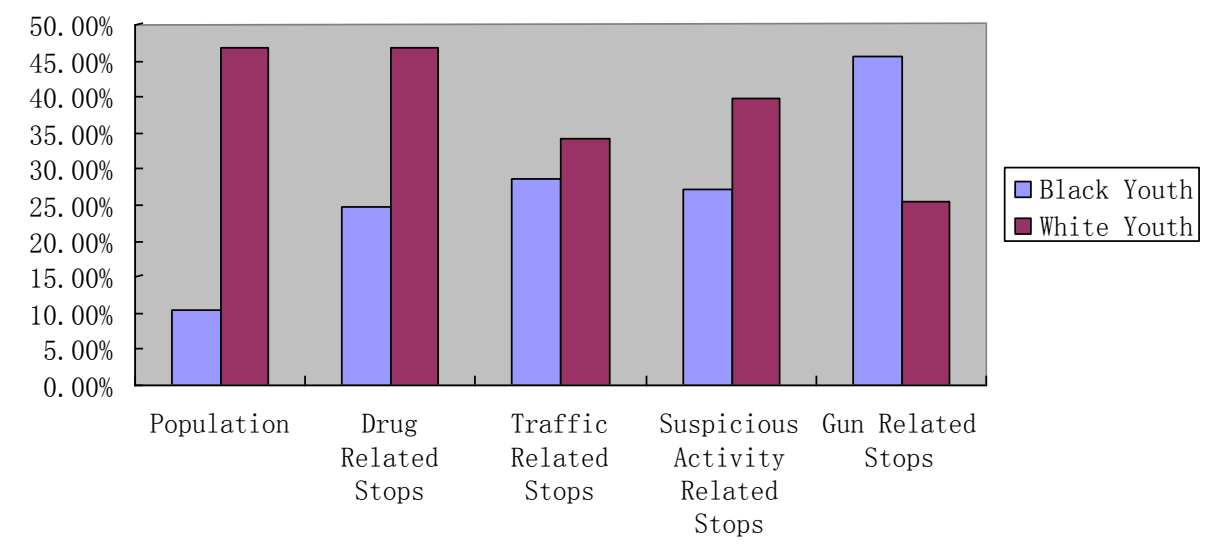

Figure 2. Percentages of ethnic population and stops for various reasons.

\subsection{Stop Rates}

At the city level, the rates of drug-, traffic-, suspicious activity-, and gun-related stops were 1.3 percent, 9.1 percent, 0.8 percent, and 0.3 percent for Black youth, respectively. The stop rate was much lower for White youth, at 0.4 percent, 2.2 percent, 0.2 percent, and 0.1 percent, respectively (see Figure 3). By comparing the stop rates, we concluded that Black youth were about 3.2, 4.1, 4, and 3 times more likely to be stopped and questioned for drug, traffic, suspicious activity, and gun-related reasons than their White counterparts. 
Discrimination in Police Stop-and-Searches

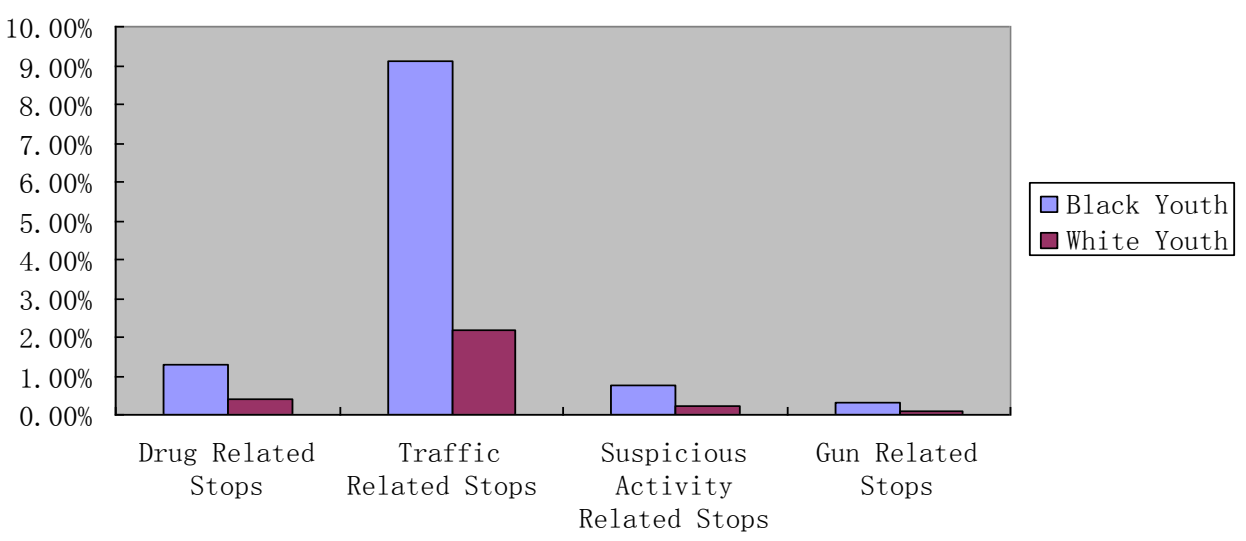

Figure 3. Stop rates by reasons.

\subsection{Summarizing the Metrics Measuring Neighbourhood Racial and Socioeconomic Characteristics}

The Spearman correlation results in Table 2 indicated that a medium level of correlation existed among the metrics measuring neighbourhood racial and socioeconomic characteristics. In other words, the information contained in the metrics was, to some extent, redundant. PCA is a statistical technique that can be used to deal with the redundancy problem and generate a smaller set of uncorrelated variables, while representing most of the information in the original set of variables (see Dunteman, 1989; Jolliffe, 2002).

Table 2

Spearman Correlation Matrix

\begin{tabular}{l|lll}
\hline & $\begin{array}{l}\text { Government transfer } \\
\text { payments }\end{array}$ & Single-parent families & White residents \\
\hline Unemployment rate & $.341^{* *}$ & $.308^{* *}$ & $-.317^{* *}$ \\
Government transfer payments & -- & $.494^{* *}$ & $-.417^{* *}$ \\
Single-parent families & -- & -- & $-.305^{* *}$ \\
\hline
\end{tabular}

\footnotetext{
$* *$ Significance level $\mathrm{p}<0.01$
} 
Meng, Giwa, and Anucha

The scree plot of the eigenvalues indicates that the first principal component (or PC 1) should be retained for representing neighbourhood racial and socioeconomic characteristics (see Figure 4). Kaiser's rule (Kaiser, 1960) retains PC 1, because it had an eignenvalue greater than 1 (see Table 3). The cumulative variance of PC 1 (56.461 percent) met the minimum requirement of 50 percent for the amount of variance accounted for, according to the cumulative variance method (see Table 3). Therefore, the results of PCA for the neighbourhood racial and socioeconomic metrics showed that PC 1 could be retained to represent the neighbourhood racial and socioeconomic characteristics.

A careful inspection of the PCA results suggests that it would be worthwhile to examine the relationship between the metrics measuring neighbourhood racial and socioeconomic characteristics and PC 2. The component contains about 18 percent of the total variance and its eigenvalue is 0.732 (see Table 3). This met the cut-off value of 0.7 , according to Jolliffe's criterion (Jolliffe, 1972). In addition, PC 1 and PC 2 accounted for more than 70 percent of the cumulative variance. This met the cut-off value for cumulative variance according to Jolliffe (2002). As a result, PC 2 was kept for further analysis. PC 3 and PC 4 only accounted for a small amount of variance compared with PC 1 and PC 2. An examination of the relationships between the metrics and PCs 3 and 4 did not reveal any interpretable pattern. Therefore, only PC 1 and PC 2 were retained for further analysis. 


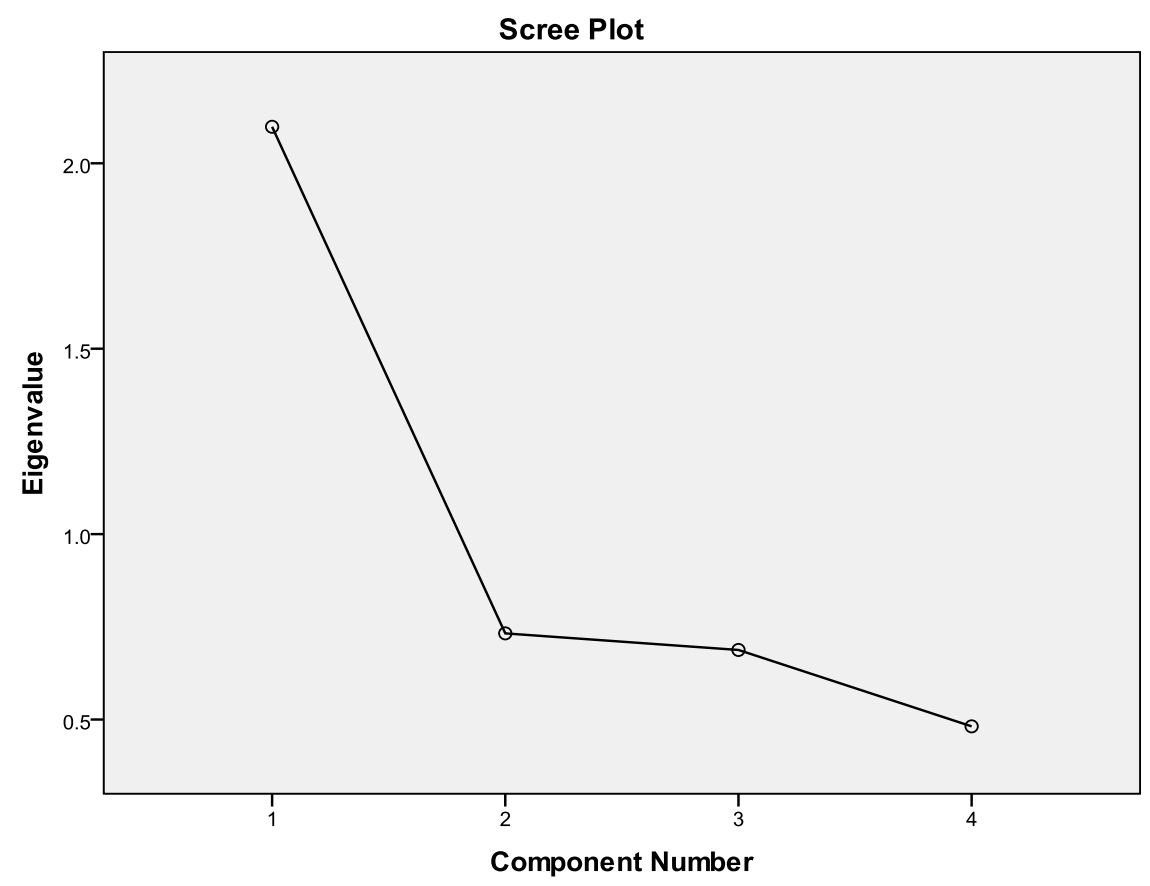

Figure 4. Scree plot of the eigenvalues from the metrics measuring neighbourhood racial and socioeconomic characteristics.

Table 3

Eigenvalues and Proportion of Variance Accounted for Each PC Extracted from the Degree of General Engagement Metrics

\begin{tabular}{l|lllll}
\hline \multirow{2}{*}{ Component } & \multicolumn{3}{|l}{ Initial eigenvalues } & \multicolumn{3}{c}{ Extraction sums of squared loadings } \\
\cline { 2 - 6 } & Total & $\begin{array}{l}\text { Percent of } \\
\text { variance }\end{array}$ & $\begin{array}{l}\text { Cumulative } \\
\text { (percent) }\end{array}$ & Percent of variance & $\begin{array}{l}\text { Cumulative } \\
\text { (percent) }\end{array}$ \\
PC 1 & 2.098 & 56.461 & 52.461 & 2.098 & 56.461 \\
PC 2 & .732 & 18.308 & 70.769 & .732 & 18.308 \\
PC 3 & .688 & 17.191 & 87.960 & & \\
PC 4 & .482 & 8.040 & 100.000 & & \\
\hline
\end{tabular}

After determining the number of components to be retained, the next step was to identify the relationships between the PCs and the metrics, and assess which metrics accounted for greater variance. A matrix of the factor loadings for each variable onto each factor or component is shown in Table 4. 
Meng, Giwa, and Anucha

Table 4

Rotated Component Matrix of the Major Components Extracted from the Metrics Measuring Neighbourhood Racial and Socioeconomic Characteristics

\begin{tabular}{l|r|r}
\hline & \multicolumn{2}{|c}{$\begin{array}{l}\text { Rotated Component Matrix } \\
\text { (Varimax normalized) }\end{array}$} \\
\hline & Factor 1 & Factor 2 \\
\hline Unemployment rate & .099 & .895 \\
Government transfer payments & .784 & .312 \\
Single-parent families & .869 & .117 \\
White residents & -.281 & -.727 \\
\hline
\end{tabular}

The factor loadings provided information about the contribution that each variable made to a component. Also, we could obtain the relationships between each metric and the two factors. The first factor was marked by high loadings on the government transfer payments and the percentage of single-parent families, since the coefficients were greater than 0.3 (Hair, Anderson, Tatham, \& Black, 1998). The relationships between Factor 1 and each metric suggested that Factor 1 was positively related with government transfer payments and the percentage of singleparent families. When it came to Factor 2, we concluded that the unemployment rate and the percentage of single-parent families and the percentage of White residents in the residential population accounted for the majority of the total variance. The correlation between Factor 2 and the unemployment rate was negative and Factor 2 was positively related with the percentage of single-parent families (see Table 4).

\subsection{The Relationships Between Neighbourhood Characteristics and the Stop Rates Involving Black Youth}

The linear regression analysis results shown in Table 5 demonstrate that Factors 1 and 2 had a significant and negative linear relationship with the stop rate involving Black youth caused by drug-related reasons, suggesting that the racial and socioeconomic characteristics of 
neighbourhoods could be a determinant for Black youth stop rates caused by drug-related reasons. Given the coefficients in Table 5, we concluded that the higher the percentage of White residents and the less the concentrated disadvantage in the neighbourhood, the greater the likelihood that Black youth were disproportionately stopped for drug-related reasons. In other words, when Black youth looked "out of place" in a White and wealthy neighbourhood, they would be subject to a higher chance of being stopped by police for drug-related reasons than in an area where their skin colour was prominent. Moreover, a combination of these two independent factors explained 44 percent of the total variability in the drug-related stop rates for Black youth. The problem of multicollinearity was not presented in the linear regression model, since the variance inflation factor (VIF) value for both factors was smaller than 10. The regression results in Table 5 also show a negative but statistically insignificant linear relationship between the stop rates for Black youth for traffic-, suspicious activity-, and gun-related reasons and the two factors.

Table 5

Results of Multiple Regression Analysis Based on the Result of Factor Analysis

\begin{tabular}{l|llcccc}
\hline Dependent Variable & Predictor & Coefficient & p value & VIF & Constant & $\mathbf{R}^{2}$ \\
\hline $\begin{array}{l}\text { Drug-related stop rate for Black } \\
\text { youth }\end{array}$ & Factor 1 & -.102 & $<.05$ & 1 & 0.595 & 0.44 \\
& Factor 2 & -.168 & $<.05$ & 1 & 0.148 \\
$\begin{array}{l}\text { Traffic related stops rate for } \\
\text { Black youth }\end{array}$ & Factor 1 & -.321 & $>.05$ & 1 & 0.22 \\
$\begin{array}{l}\text { Suspicious activity-related stops } \\
\text { for Black youth }\end{array}$ & Factor 2 & -.521 & $>.05$ & 1 & 1 & -0.004 \\
& Factor 1 & -.021 & $>.05$ & 1 & 0.08 \\
$\begin{array}{l}\text { Gun-related stops for Black } \\
\text { youth }\end{array}$ & Factor 2 & -.005 & $>.05$ & 1 & 1 & 0.007 \\
\hline
\end{tabular}


Meng, Giwa, and Anucha

\section{Discussion}

\subsection{Racial Profiling of Black Youth}

The primary purpose of our study was to examine whether Toronto police engaged in racial profiling of Black youth. We found that Black youth were subject to disproportionately more stops than their White counterparts. Some researchers, and the Toronto police themselves, have often argued that the disproportionate stop rate of Black youth is not the result of racial profiling, but is instead a response to a high crime rate among Black youth and a policing strategy that is pragmatic and efficient (Bratton \& Knobler, 1998; Goldberg, 1999; Toronto Police Accountability Coalition, 2010; Winsa \& Rankin, 2012). However, it is highly questionable and controversial to use a race-specific crime rate as the base evidence to support a race-specific stop rate, since crime statistics showing that certain minority groups are more inclined to commit a particular type of crime than White people often contain bias as well.

Indeed, official crime data may be a measure of official reactions to crime rather than a measure of the actual crime rate itself (Warner \& Pierce, 1993, p. 494). In this sense, a high Black crime rate may simply represent a strong predilection for social control by the police. In one study, White youth in Toronto had a much higher rate of illicit drug use than Black youth, yet Black youth reported a higher rate in drug possession charges (Wortley \& Tanner, 2004). Therefore, there is no sound basis for police to disproportionately stop Black youth for drug, traffic, and gun-related reasons, since there is no reason to believe that Black youth are consistently more inclined to commit these different types of crime than White youth in Toronto.

In addition, contrary to the suggestion that the disproportionate number of stops of Black youth helps use police resources efficiently, we argue that such stops are actually inefficient police practices: to stop Black youth disproportionately, the police must allocate disproportionately more resources to targeting innocent Black youth. Disproportionately fewer 
Discrimination in Police Stop-and-Searches

resources must therefore be assigned to search for actual offenders, since police have limited resources at any given time. Hence, the disproportionately higher number of police stops of Black youth suggest racial profiling on the part of Toronto police, as opposed to representing reasonable and efficient police practices.

Racial profiling of Black youth in Toronto may produce hidden distortions in crime statistics since this disproportionate number of stops may lead to more arrests. Guided by problem-oriented policing strategies, current arrest statistics would indicate that relatively greater numbers of Black youth would be stopped by Toronto police in the future. Gradually, this could become a vicious cycle. This has happened before. For example, between 1986 and 1992, police intensified their patrol of disadvantaged areas in Ontario and unevenly targeted Black people as suspects. As a result of these actions, Black people were overrepresented in prisoner statistics, according to the Ontario Systemic Racism Commission (Wortley, 2006). The perceived success of profiling Blacks, signalled by their high incarceration rates, fuelled the existing stereotype that young Black males were likely to be involved in drug-related crimes, which in turn contributed to even more overt racial profiling (Bahdi, with Parsons \& Sandborn, 2007). Eventually, this tooloosely based Black criminal profile meant that any Black male, regardless of his age or location, was considered a potential threat (Bahdi et al., 2007).

\subsection{Race-and-Place Profiling}

The second objective of our study was to examine the association between neighbourhood characteristics and Black youth stop rates. Our study suggests that Toronto police might also be engaging in race-and-place profiling of Black youth, for our results show that Black youth were more likely to be stopped due to drug-related reasons in neighbourhoods that were less disadvantaged and where more White people resided. These findings corroborate the view that Toronto police are more likely to stop Black youth who look "out of place" and provide 
more empirical evidence to support the racial threat theory (Blalock, 1967; Blumer, 1958).

Racial threat theory suggests that minority groups not only become a demographic threat to White people as their presence in the population grows, but also, in addition, if not in a subordinate position, they also threaten White socioeconomic advantage, cultural and political dominance, and even feelings of superiority. The use of formal social control is therefore deemed necessary to reduce these threats. One such formal social control is represented by-and implemented through — the disproportionate number of police stops of Black youth in less disadvantaged neighbourhoods dominated by White people. We also found that a low stop rate of Black youth was more likely in areas where the White residential population was low and community disadvantage was high. We believe this phenomenon can be explained by the concept that Black youth pose less of a threat to White social, political, and economic interests when they are inside their racialized and disadvantaged neighbourhoods.

Furthermore, it is still questionable whether formal social control efforts implemented at the agency level (such as the TPS) can completely neutralize race-and-place profiling charges against individual police officers. For example, when police officers carry out a stop-and-search, their decision to do so is often influenced by a subjective perception (or even a biased personal knowledge) of the suspects, crimes, and patrol areas gained through previous experiences or information from fellow officers (Smith et al., 2004). Race, together with place, may be used as a proxy for actual threat or, at a minimum, for reasonable suspicion in a police stop. Thus, a police officer's response to similar cases may differ significantly, depending on the characteristics of the neighbourhood and the racial background of the suspect. For example, an officer meeting a Black youth in a predominantly White neighbourhood might overreact simply out of an exaggerated perception of risk. If this is the case, Black youth might experience excessive 
Discrimination in Police Stop-and-Searches

policing in this particular neighbourhood, not because of any formal social control efforts at the agency level, but because of abuse of discretion at the individual-officer level.

Our study shows a paradox: given the study's racial profiling and race-and-place profiling findings, it appears that Toronto's democratic society needs protection both by police and from police. The solution calls for democratic policing, a term often understood as seeking an equitable distribution of police service or police control over the public (Roh \& Robinson, 2009). Central to the concept of democratic policing is community control of the police through community empowerment and community participation (Sklansky, 2008). That is, the police should engage the community to create and maintain trust relationships and take racial diversity into account when devising policing strategies. The public must participate in policing decisionmaking processes and determine the amount and types of police services and police protection necessary. Instead of reacting to crime only after it occurs, democratic policing calls on the police to implement organizational changes that would support the proactive prevention of crime and social disorder through community partnerships and systematic problem solving.

As a law enforcement organization, the police should be attracted to pursuing the ideal of democratic policing. However, problem-oriented policing strategies, which require the disproportionate deployment of police resources in different locations and the disparate treatment of different neighbourhoods, can conflict with the goal of democratic policing. Nevertheless, to minimize conflict, Toronto police must take into consideration the community's demands and have the community's support, when developing a policing strategy.

\subsection{Limitations}

This study was not without limitations. First, the use of population census data as the benchmark could have created two interrelated errors: base error and aggregation error. Population census data are an appropriate denominator for statistics that measure prevalence. 
Meng, Giwa, and Anucha

However, counts of police stops — the numerator in racial profiling studies - measure incidence or counts of events. Consequently, base error can be generated when using counts of police stops divided by population figures from census data. Moreover, a small group of individuals belonging to one race can be stopped a large number of times, thus inflating the race-specific stop data, which can result in aggregation error.

Second, the use of population census data as the benchmark could be associated with an assumption that police stops are practised randomly. However, this assumption is often vitiated since the police usually carry out stop-and-searches in areas where they most anticipate problems. Third, people stopped in a neighbourhood are not necessarily residents living in that neighbourhood. Because population census data do not provide the racial composition information of pass-by people, the Black and White stop rates, as a result, can be overestimated. Fourth, the skin colour data recorded in the 208 cards do not always correspond to race/ethnicity data in the Canadian census. For example, Toronto police could have difficulties distinguishing dark-skinned South Asians from Blacks or differentiating Arabs or Latin Americans from Whites based on their appearance. Thus, chances are that youth who were coded as Black or White in the 208 cards might be counted as belonging to other ethnicities in the Canadian census. If this is the case, the number of Black or White youth in the stop data is not accurate. Given these limitations, the findings and discussion in our study must be regarded as preliminary or exploratory rather than conclusive.

\section{Conclusions}

In general, the issue of racial profiling in policing has not been examined as deeply in Canada as it has been in the United States. In Canada, racial profiling studies focusing on Black youth and/or neighbourhood-based processes are very limited. Our study contributes empirically to research into racial profiling of Black youth in Toronto and demonstrates that members of the 
Discrimination in Police Stop-and-Searches

city's police force are susceptible to racially influenced policing. As discussed in this paper, the disproportionate stop-and-search rate of Black youth is not an appropriate response to a high crime rate among Black youth and does not represent reasonable and efficient police practices. Instead, racial profiling can cause irreparable harm to the relationship between members of the police force and the racialized communities in the city.

Our study also demonstrated how neighbourhood characteristics can contribute to spatial variations of police stops involving Black youth, as well as suggesting that Toronto police might engage in race-and-place profiling of Black youth when it comes to drug-related stop-andsearches. Previous racial profiling studies done in Toronto were carried out at city-wide level, ignoring neighbourhood-level processes (see Gold \& Harvey, 2003; Melchers, 2003; Wortley \& Tanner, 2003, 2004). This is largely due to the difficulty in linking racial profiling at the individual-officer level to the ecological context of neighbourhoods. This study shows that the theoretical literature in sociology on neighbourhood characteristics can contribute to an understanding of the relationship between race and police stops in the context of neighbourhood.

In terms of the implications for Toronto police, our research emphasizes that police personnel should recognize that policing strategies should be based on sound research, have the support of the community, and ensure effective crime control while maintaining principles of democratic policing. Police personnel in the field should be informed that race is not a useful predictor of criminality, either as a sole factor or in combination with other factors (such as location). Police personnel should also understand that not only are there legal and moral concerns about targeting Black youth for stop-and-search, but also that doing so is not an effective crime-control strategy. Furthermore, racial profiling or race-and-place profiling destroys public trust in and support for the police. 
Meng, Giwa, and Anucha

Clearly, the issue of racial profiling in Toronto requires further research. First, police stop-and-search data do not contain details on the nature of the police-citizen contact for each individual case. For example, it is impossible to obtain information on whether physical assault, emotional mistreatment, or abusive language played a role in any given stop. Therefore, followup interviews are needed to collect such information, and further qualitative theoretical and empirical research on this front is warranted. Second, the data do not describe the transportation mode (i.e., walking, driving, or biking) of the stopped youth. Such information would make it possible to compare stop rates for people from the same race but using different forms of transportation, since racial bias is more likely to be introduced in police interaction with pedestrians and bikers whose skin colour is known before they are stopped. Third, this research cannot overcome the weaknesses associated with the population benchmark used in this study. Future research should adopt an alternate benchmark to calculate stop rates more accurately. Fourth, this paper is mainly focused on one phenomenon of racially biased policingoverpolicing of racial minorities. Future research is needed to address the underpolicing issue and explore its causes.

\section{Acknowledgement}

This research was supported by grants from the CSU-AAUP, the Ontario Ministry of Research and Innovation, and Social Sciences \& Humanities Research Council of Canada (SSHRC), for which the authors are indebted. 
Discrimination in Police Stop-and-Searches

\section{References}

Bahdi, R., with Parsons, O., \& Sandborn, T. (2007). Racial profiling: B.C. Civil Liberties Association position paper. In R. Bahdi, R. Bent, I. Cohen, F. Henry, R. Holmes, B. Jackman, D. Moeckli, ... R. Whitaker, Racial profiling: A special BCCLA report on racial profiling in Canada (pp. 31-54). Retrieved from http://bccla.org/wpcontent/uploads/2012/03/2007-BCCLA-Report-Racial-Profiling.pdf

Bass, S. (2001). Out of place: Petit apartheid and the criminal justice system. In D. Milovanovic \& K. K. Russell (Eds.), Petit apartheid in the U.S. criminal justice system: The dark figure of racism (pp. 43-53). Durham, NC: North Carolina Academic Press.

Beyer, H. L. (2004). Hawth's analysis tools for ArcGIS. Retrieved from http://www.spatialecology.com/htools

Bittner, E. (1970). The functions of police in modern society. Rockville, MD: National Institute of Mental Health.

Blalock, H. M. (1967). Toward a theory of minority-group relations. New York, NY: Wiley.

Blumer, H. (1958). Race prejudice as a sense of group position. Pacific Sociological Review, 1, 3-7.

Blumstein, A. (1982). On the racial disproportionality of United States' prison populations. Journal of Criminal Law \& Criminology, 73(3), 1259-1281.

Bostaph, L. (2007). Race and repeats: The impact of officer performance on racially biased policing. Journal of Criminal Justice, 35(4), 405-417.

Bratton, W., \& Knobler, P. (1998). Turnaround. New York, NY: Norton.

Brown, M. K. (1981). Working the street: Police discretion and the dilemmas of reform. New York, NY: Russell Sage Foundation. 
Meng, Giwa, and Anucha

Brown, M., \& Warner, B. (1992). Immigrants, urban politics, and policing in 1900. American Sociological Review, 57(3), 293-305.

Buerger, M. (2009). Racial profiling. In J. Miller (Ed.), 21st century criminology: A reference handbook. Thousand Oaks, CA: Sage.

Bursik, R. J. (1988). Social disorganization and theories of crime and delinquency: Problems and Prospect. Criminology, 26, 519-551.

City of Toronto (2013). Toronto Facts. Retrieved from http://www1.toronto.ca/wps/portal /contentonly?vgnextoid=57a12cc817453410VgnVCM10000071d60f89RCRD

Doerner, W. (1997). An introduction to law enforcement: An insider's view. New York, NY: Butterworth-Heinemann.

Dunteman, G. H. (1989). Principal components analysis (Sage University Paper Series on Quantitative Applications in the Social Sciences, No. 07-069). Newbury Park. CA: Sage.

Eid, P., Magloire, J., \& Turenne, M. (2011). Racial profiling and systemic discrimination of racialized youth. Montreal: Commission des Droits de la Personne et des Droits de la Jeunesse.

Engel, R., \& Calnon, J. (2004). Examining the influence of drivers' characteristics during traffic stops with police: Results from a national survey. Justice Quarterly, 21(1), 49-90.

Engel, R., Calnon, J., \& Bernard, T. (2002). Theory and racial profiling: Shortcomings and future directions in research. Justice Quarterly, 19(2), 249-273.

Fong, E. (1996). A comparative perspective on racial residential segregation: American and Canadian experience. The Sociological Quarterly, 37(2), 199-226.

Foster, C. (1996). A place called heaven: The meaning of being black in Canada. Toronto, ON: Harper-Collins. 
Discrimination in Police Stop-and-Searches

Gamble, T., Benekos, P., Hale, W., Gambill, P., Danzer, A., Exner, K., \& Haltigan, J. (2002). Analysis of police stops and searches. Erie, PA: Mercyhurst College, Civic Institute.

Giwa, S., James, C. E., Anucha, U., \& Schwartz, K. (2014). Community policing-a shared responsibility: A voice-centered relational method analysis of a police/youth-of-color dialogue. Journal of Ethnicity in Criminal Justice. Advance online publication. doi: $10.1080 / 15377938.2013 .837856$.

Gold, A., \& Harvey, E. (2003). Executive summary of presentation on behalf of the Toronto Police Service. Toronto, ON: Toronto Police Service.

Goldberg, J. (1999). The color of suspicion. New York, NY: New York Times.

Gudell J., \& Skogan, W. (2003). Community mobilization for community policing. Journal of the American Statistical Association, 101, 878-887.

Hair, J. F., Anderson, R. E., Tatham, R. L., \& Black, W. C. (1998). Multivariate data analysis. Englewood Cliffs, NJ: Prentice Hall.

Harney, R. (1985). Ethnicity and neighbourhoods. In R. Harney (Ed.), Gathering places: Peoples and neighbourhoods of Toronto. Toronto, ON: Multicultural History Society of Ontario.

Harris, D. (1997). "Driving while Black" and all other traffic offenses: the Supreme Court and pretextual traffic stops. The Journal of Criminal Law and Criminology, 87(2), 544-582.

Harris, D. (1999). The stories, the statistics, and the law: Why "driving while Black" matters. Minnesota Law Review, 84(2), 265-326.

Harris, D. (2003). Profiles in injustice: Why racial profiling cannot work. New York, NY: The New Press. 
Meng, Giwa, and Anucha

Harvey, E. B., \& Liu, R. (2003, March). An independent review of the Toronto Star analysis of criminal information processing system (CIPS) data provided by the Toronto Police Service (TPS). Retrieved from http://torontopolice.on.ca/publications/files /reports/harveyreport.pdf

Herbert, S. (1997). Policing space: Territoriality and the Los Angeles police department. Minneapolis, MN: University of Minnesota Press.

Hotelling, H. (1933). Analysis of a complex of statistical variables into principal components. Journal of Educational Psychology, 24, 417-441, 498-520.

Hou, F., \& Picot, G. (2004, Spring). Visible minority neighbourhoods in Toronto, Montreal and Vancouver. Canadian Social Trends, 72, 8-13.

Jolliffe, I. T. (1972). Discarding variables in a principal component analysis I: Artificial data. Applied Statistics, 21(2), 160-173.

Jolliffe, I. T. (2002). Principal component analysis. Secaucus, NJ: Springer-Verlag.

Kaiser, H. F. (1960). The application of electronic computers to factor analysis. Educational and Psychological Measurement, 20, 141-151.

Krivo, L., \& Peterson, R. D. (1996). Extremely disadvantaged neighborhoods and urban crime. Social Forces, 75, 619-648.

Land, K. C., McCall, P., \& Cohen, L. E. (1990). Structural covariates of homicide rates: Are there any invariances across time and social space? American Journal of Sociology, 95, $922-963$.

Lurigio, A., Greenleaf, R., \& Flexon, J. (2009). The effects of race on relationships with the police: A survey of African American and Latino youths in Chicago, Western Criminology Review, 10(1), 29-41. 
Discrimination in Police Stop-and-Searches

Mardia, K. V., Kent, J. T., \& Bibby, J. M., (1979). Multivariate analysis. New York, NY: Academic Press.

Meehan, A., \& Ponder, M. (2002). Race and place: The ecology of racial profiling African American motorists. Justice Quarterly, 19(3), 399-430.

Melchers, R. (2003). Do Toronto police engage in racial profiling? Canadian Journal of Criminology and Criminal Justice, 45(3), 347-366.

Milovanovic, D., \& Russell, K. K. (2001). Petit apartheid in the U.S. criminal justice system: The dark figure of racism. Durham, NC: North Carolina Academic Press.

Myers, M. (1990). Black threat and incarceration in postbellum Georgia. Social Forces, 69(2), $373-393$.

Neugebauer, R. (2000). Kids, cops, and colour: The social organization of police-minority youth relations. In Neugebauer R. (Ed.), Criminal injustice: Racism in the criminal justice system. Toronto, ON: Canadian Scholars Press.

Ontario Human Rights Commission. (2003, October 21). Paying the price: The human cost of racial profiling (Inquiry Report). Retrieved from http://www.ohrc.on.ca/en/resources /discussion_consultation/RacialProfileReportEN/pdf

Parker, K. F., \& McCall, P. L. (1999). Structural conditions and racial homicide patterns: A look at the multiple disadvantages in urban areas. Criminology, 37, 447-478.

Parker, K. F., MacDonald, J. M., Alpert, G. P., Smith, M. R., \& Piquero, A. (2004). A contextual study of racial profiling: Assessing the theoretical rationale for the study of racial profiling at the local level. American Behavioral Scientist, 47, 943-962.

Paulsen, D., \& Robinson, M. (2004). Spatial aspects of crime: Theory and practice. Boston, MA: Allyn \& Bacon. 
Meng, Giwa, and Anucha

Rankin, J., Quinn, J., Shephard, M., Simmie, S. \& Duncanson, J., (2002a, October 20). Police target Black drivers. Toronto Star, p. A1.

Rankin, J., Quinn, J., Shephard, M., Simmie, S. \& Duncanson, J., (2002b, October 19). Singled out: An investigation into race and crime. Toronto Star, October 19, 2002, p. A1.

Rankin, J. (2010, February 6). Race matters: Blacks documented by police at high rate. Toronto Star. Retrieved from http://www.thestar.com/specialsections/raceandcrime/article /761343--race-matters-blacks-documented-by-police-at-high-rate

Ricketts, E., \& Sawhill, I. (1988). Defining and measuring the underclass. Journal of Policy Analysis and Management, 7, 316-325.

Roh, S., \& Robinson, M. (2009). A geographic approach to racial profiling: The microanalysis and macroanalysis of racial disparity in traffic stops. Police Quarterly, 12(2), 137-169.

Sampson, R. J. (2000). Whither the sociological study of crime? Annual Review of Sociology, 26, $711-714$.

Shaw, C. R., \& McKay, H. D. (1942). Juvenile delinquency and urban areas. Chicago, IL: University of Chicago Press.

Sherman, L. W., Gartin, P. R., \& Buerger, M. E. (1989). Hot spots of predatory crime: Routine activities and the criminology of place. Criminology, 27, 27-55.

Short, J. F. (1998). The level of explanation problem revisited: The American Society of Criminology 1997 Presidential Address. Criminology, 36, 3-36.

Sklansky, D. A. (2008). Democracy and the police. Stanford, CA: Stanford University Press.

Smith, D. A. (1986). The neighborhood context of police behavior. In A. J. Reiss \& M. Tonry (Eds.), Crime and justice: An annual review of research. Chicago, IL: University of Chicago Press. 
Discrimination in Police Stop-and-Searches

Smith, W., Tomaskovic-Devey, D., Zingraff, M., Mason, M., Warren, P., \& Wright, C. (2004). The North Carolina Highway Traffic Study. Retrieved from http://www.ncjrs.gov /pdffiles1/nij/grants/204021.pdf

Spearman, C. (1904). General intelligence, objectively determined and measured. American Journal of Psychology, 15, 201-293.

Statistics Canada. (2006a). Ethnic origin and visible minorities. Retrieved from https://www12.statcan.gc.ca/census-recensement/2006/rt-td/eth-eng.cfm

Statistics Canada.(2006b). Youth profile data. Ottawa, ON: Author.

Stults, B., Parker, K., \& Lane, E. (2010). Space, place, and immigration: New directions for research on police stops. In S. K. Rice \& M. D. White (Eds.), Race, ethnicity and policing: New and essential readings (pp. 411-424). New York, NY: NYU Press.

Tanovich, D. (2002, Summer). Using the Charter to stop racial profiling: The development of an equality-based conception of arbitrary detention. Osgoode Hall Law Journal, 40(2), 145187.

Tanovich, D. (2007). One list for air travellers, one list for Black youth. Toronto Star. Retrieved from http://www.thestar.com/comment/article/232546

Toronto Police Accountability Coalition. (2010, March 12). Toronto Police Accountability Bulletin (No. 52). Retrieved from http://tpac.ca/show_bulletin.cfm?id=141

Toronto Police Service (2003). Independent review final report. Retrieved from http://www.torontopolice.on.ca/modules.php?op=modload\&name=News\&file= article\&sid=386

Warner, B. D., \& Pierce, G. L. (1993). Reexamining social disorganization theory using calls to the police as a measure of crime. Criminology, 31, 493-516. 
Meng, Giwa, and Anucha

Wilson, W. J. (1987). The truly disadvantaged: The inner city, the underclass, and public policy. Chicago, IL: University of Chicago Press.

Wilson, W. J. (1996). When work disappears: The world of the new urban poor. New York, NY: Knopf.

Winsa, P., \& Rankin, J. (2012, April 14). Police Service Board decision on “carding” stuns activists. Toronto Star. Retrieved from http://www.thestar.com/news/gta/2012/04/14 /police_service_board_decision_on_carding_stuns_activists.html

Wortley, S. (2006). Racial Profiling in Canada: Evidence, impacts and policy debates. Toronto, ON: Faculty of Law, University of Toronto.

Wortley, S., \& Tanner, J. (2003). Data, denials and confusion: The racial profiling debate in Toronto. Canadian Journal of Criminology and Criminal Justice, 45(3), 367-390.

Wortley, S., \& Tanner, J. (2004). Discrimination or good policing? The racial profiling debate in Canada. Our Diverse Cities, 1, 197-201. 